\title{
ECONOMIC ASPECTS OF MILK PRODUCTION AND \\ TRADITIONAL DAIRY PRODUCTS ON AGRICULTURAL FARMS IN THE REPUBLIC OF SERBIA
}

\author{
Vedran Tomićl, Dragan Milić2 ${ }^{2}$, Dejan Janković ${ }^{3}$ \\ *Corresponding author E-mail: vtomic@ipn.bg.ac.rs
}

A R T I C L E I N F O
Original Article
Received: 13 June 2020
Accepted: 25 July 2020
doi:10.5937/ekoPolj2003881T
UDC
330:[637.1:631.1.017.3(497.11)

Keywords:

economic aspects, dairy farms, milk production and processing, competitiveness, production costs

JEL: Q10, Q12

\begin{abstract}
A B S T R A C T
Serbia has favorable natural conditions for the development of livestock production, especially the cow's milk production. Average milk production is 1.5 billion liters per year and the dominant share is produced on small farms. Only $35.1 \%$ of the total amount of milk produced in Serbia is processed. The subject of this research are economic aspects of milk production and processing into skimmed cream and white cheese on family farms. For that purpose, the model for the production of traditional milk products on family farms was developed and analysed, by using the method of analytical calculation based on variable costs. The results have shown that the difference between the production price per liter of raw vs. processed milk was $€ 0.24$, while between the selling price of raw and processed milk per liter was $€ 1$. Farms with up to 15 dairy heads should consider milk processing, i.e. finalization of products.
\end{abstract}

(C) 2020 EA. All rights reserved.

\section{Introduction}

Republic of Serbia has favorable natural conditions for the development of livestock production, especially the cow's milk production. According to official statistics, there were a total of 424,155 dairy cows in Serbia in 2018. In terms of the number of dairy cows, Serbia is the leader in the region (Milic et al., 2019). Milk production is mainly produced by family farms with less than ten dairy cows. More than $59 \%$ of producers have one to two heads and an average daily milk delivery of 19.4 liters per farm. The

1 Vedran Tomić, M.Sc., Research Associate, Institute for Science Application in Agriculture, 68b Blvd. despota Stefana, 11000 Belgrade, Serbia, Phone: +381 112751 622, E-mail: vtomic@ipn.bg.ac.rs, ORCID ID (https://orcid.org/0000-0003-2383-721X)

2 Dragan Milić, Ph.D., Assistant Professor, University of Novi Sad, Faculty of Agriculture, Trg Dositeja Obradovića 8, 21000 Novi Sad, Serbia, Phone: +381 214853 274, E-mail: dragan.milic@polj.edu.rs, ORCID ID (http://orcid.org/0000-0003-0377-1540)

3 Dejan Janković, Ph.D., Associate Professor, University of Novi Sad, Faculty of Agriculture, Trg Dositeja Obradovića 8, 21000 Novi Sad, Serbia, Phone: +381 21 4853381, E-mail: jankovic@polj.uns.ac.rs, ORCID ID (https://orcid.org/0000-0002-2609-125X)

http://ea.bg.ac.rs 
second group of producers (35\%) has three to nine heads, while almost $95 \%$ of milk producers are small family farms with a maximum of 9 dairy cows. One of the main limiting factors for increasing the number of cows on the majority of family farms in the Republic of Serbia is the fragmentation of hosueholds, i.e. limited resources for the production of animal feed. Milk processing into recognizable traditional products enables achieving better economic results since milk is valued through final products that have added value. Traditional dairy products are biologically valuable foodstuffs that can be sold in green markets or on the family farms. They can also play a significant role in the development of rural tourism, as they could significantly complement the tourist offer of our country.

Considering pronounced migration tendencies between the village and the city and the large number of abandoned villages in Serbia, the question that arises is: what are the possibilities to increase income on farms and to make rural life economically sustainable. According to the data of the survey regarding the structure of agricultural households, there is the estimation that the total number of inhabitants in Serbia will fall to the level below 7 million (Survey on the structure of agricultural holdings, $2018,2019)$. The process of population outflow is happening in two directions, i.e. by increasing the number of inhabitants in urban areas to the detriment of rural areas, but also by the mass leaving of young people abroad. If we observe the negative trend of the share of rural population in the total number in the Republic of Serbia from World War II to present, it can be expected in the 2021 Census, the share of rural population will be at the level of about 35\% (Mitrović, 2015). Another important thing is the fact that the population reproduction is higher in rural areas. Therefore, the pronounced migration from villages to cities affects the population aging. Western Europe faced this phenomenon much earlier, and today it fills the empty areas by migration.

If we analyze the production value by activities in the Republic of Serbia for the period from 2000 to 2017, it can be concluded that crop production is dominant activity (52\%), which, as a rule, represents extensive production and does not require hiring a large number of employees (Popescu \& Andrei, 2011). Cattle breeding is represented only by $13.2 \%$. According to the survey from 2018 , the total number of agricultural farms is $12 \%$ lower as compared to the number of farms from the 2012 Census of Agriculture.

Despite the fact that the economic size was higher in $2018(€ 8,610)$ by $45 \%$, compared to the results of the 2012 Census, the economic size or value of production generated by farms in EU countries is 4 times higher than on farms in Serbia (EUROSTAT, 2016). Many authors consider that $15 \%$ of this production value remains as profit and work compensation, which would mean, for example, that a farm with a production value of $€ 20,000$ per year has a balance of $€ 3,000$ per year, which, when divided by 12 months is $€ 250$ per month, i.e. a minimum average month salary. When observing indicators by regions in Serbia, the data on the average economic size show that the highest incomes are achieved in farming, as well as that these farms are located in the region of AP Vojvodina. On the other hand, the largest number of farms engaged in 
livestock production is located in Šumadija and Western Serbia. The total amount of processed milk in Serbia is 524.1 million liters per year, which is only $35.1 \%$ of the total amount of raw milk produced in Serbia in 2018 (about 1.5 billion liters) (Ministry of Agriculture, Forestry and Water Management, Veterinary Directorate, 2019).

By introducing adequate technology, a significant amount of milk can be processed into traditional milk products within family farms, such as various types of cheese and other dairy products that can be successfully valorized on the market. This can significantly increase the value of milk and thus the profitability of milk production (Popović Vranješ et al., 2017). Traditional dairy products are characterized by original technology and specific properties, determined by the areas where milk is produced. They are recognizable on the market, which provides the opportunity to create significant added value (Popović Vranješ, 2015).

Milk processing into traditional dairy products can be considered as a form of diversification of agricultural production, as well as creation of added value on farms. Diversification of the rural economy and the income of the rural population, engages additional activities, which may or may not be related to the production or processing of food on the farm, can have a positive effect on the overall economic growth and the preservation of rural areas. Diversification provides additional income on the farm, thus improving standards of living, reducing household vulnerability in terms of income. One of the main causes of rural poverty in Serbia is the high dependence of the rural economy on agriculture and insufficiently diversified economic structure (Janković and Novakov, 2019). Furthermore, some authors (Chaplin, Davidova and Gorton 2004, according to Janković et al., 2014) define diversification as a process of reducing dependence on agriculture. Depending on many factors on farms, but also in the local community, the region and society as a whole, it is possible to expect a greater or less degree of diversification on farms/households in rural areas. Davis and Pearce (2000) (according to Janković et al., 2014) emphasize the following influencing factors: household characteristics (availability of additional labor, gender patterns and constraints, decision-making responsibilities), education, and skills (which appear to have a significant impact on employment out of farm, rather than participation in onfarm activities); access to finance (which may or may not always be linked to land and farm size), infrastructure (which can stimulate growth and employment - access to jobs), social capital (as vertical and horizontal networks and different conditions for their access, due to different socio-economic status).

In this research economic aspects of milk production and processing into skimmed cream and white cheese on small family farms were investigated. Also, the aim of the research was to analyze the possibility of increasing farm income through the milk processing into traditional products. 


\section{Materials and methods}

The research included the analysis of economic indicators of milk production and milk processing into skimmed cream and white semi-fat cheese in mini plants on family farms in 2017. Data on production and economic results of mini dairies were collected through the field survey. In order to gain insight into the current state of the dairy sector in Serbia and the world, data from the publications of the Statistical Office of the Republic of Serbia, STIPS and EUROSTAT were used.

Analytical calculation based on variable costs (Direct costing method) is a fast and efficient indicator for comparing different production lines and selecting the most cost effective one (Tomić et al., 2013). It enables the current economic analysis of the production, i.e. the assessment of economic sustainability of the production technology and the achieved results (Subić et al., 2015; Nielsen et al., 2015). This is more suitable procedure compared to the analytical calculation of the full unit costs, which requires to separate fixed costs for individual production lines, as well as to express not only direct but also overhead costs. Therefore, analytical calculation of the full unit cost is complicated, since family farms don't have legal obligation to keep accounting records.

The subject of this research are the economic aspects of production and processing of milk into skimmed cream and white semi-fat cheese in mini plants on family farms with a capacity of up to 200 liters milk processing per day. Both productions were tested on the basis of the analysis of production capacities and business results of the representative farm which is exclusively engaged in raw milk production.

The aim of the research is to calculate the raw milk production costs per liter, as well as the production costs of processed liter of milk into traditional milk products skimmed cream and white semi-fat cheese, and assess the economic efficiency of both productions.

The method of analytical calculation based on variable costs (Direct costing method) was used in the analysis, since this method is most often used when analyzing economic data on small family farms that do not have the obligation to keep accounting records.

The general scheme of analytical calculation based on variable costs is the following (Andrić, 1998; Gogić, 2014):

$$
\mathrm{PV}-\mathrm{VC}=\mathrm{GM}
$$

whereas the following means:

$\mathrm{PV}$ - Total production value in specific production;

$\mathrm{VC}$ - Total variable costs for each production line;

GM - Gross margin (gross financial result). 


\section{Results with Discussions}

Based on the analysis of field research results, and by using the gross margins as a methodology tool, a farm model was set up and used for the analysis of economic efficiency in milk production and processing. The farm model was formed on the basis of the average values of 242 farms in the surveyed sample. The farms from the sample are located throughout Serbia, more precisely in 68 municipalities.

Table 1. Starting indicators in the model

\begin{tabular}{|l|r|r|}
\hline Number of dairy cows & 12 & Cows \\
\hline Average age of dairy cows & 5 & Years \\
\hline Average milk yield & 4,211 & lit/head \\
\hline Average euro exchange rate & 121.34 & RSD \\
\hline Production year & 2017 & \\
\hline
\end{tabular}

Source: Authors' calculations

Table 2 shows the structure of production value and variable costs in milk production.

Table 2. Gross margin of the variable costs in milk production

\begin{tabular}{|c|c|c|c|c|c|}
\hline Description & Quantity & Unit & Unit price $(€)$ & Total $(€)$ & Per head $(€)$ \\
\hline \multicolumn{6}{|l|}{ A. Production value } \\
\hline Milk sold to the dairy & 50,536 & lit & 0.23 & $11,661.51$ & 971.79 \\
\hline Male calves sold & \multicolumn{2}{|c|}{$\begin{array}{c}6 \\
\text { head }\end{array}$} & 593.37 & $3,560.24$ & 296.69 \\
\hline Female calves sold & 2 & head & 461.51 & 923,03 & 76.92 \\
\hline Heifers sold & 2 & head & $1,500.00$ & $3,000.00$ & 250.00 \\
\hline Culled cows & 2 & head & 803.53 & $1,607.05$ & 133.92 \\
\hline Milk premium & 50,536 & lit & 0.06 & $2,915.38$ & 242.95 \\
\hline $\begin{array}{l}\text { Subsidy for milking } \\
\text { cows }\end{array}$ & 12 & head & 206.03 & $2,472.39$ & 206.03 \\
\hline \multicolumn{4}{|l|}{ Manure } & 988.96 & 82.41 \\
\hline \multicolumn{4}{|c|}{ Production value (Total A) } & $27,128.56$ & $2,260.71$ \\
\hline \multicolumn{6}{|c|}{ B. Variable costs } \\
\hline \multicolumn{4}{|l|}{ Feed } & $11,940.85$ & 995.07 \\
\hline \multicolumn{4}{|l|}{ Labour } & $2,707.27$ & 225.61 \\
\hline \multicolumn{4}{|l|}{ Energy and fuel } & 540.03 & 45.00 \\
\hline \multicolumn{4}{|l|}{ Contract work } & 765.00 & 63.75 \\
\hline \multicolumn{4}{|l|}{ Other } & 385.76 & 32.15 \\
\hline \multicolumn{4}{|l|}{ Variable costs (Total B) } & \begin{tabular}{|l|l|}
$16,338.91$ \\
\end{tabular} & $1,361.58$ \\
\hline \multicolumn{4}{|l|}{ C. Gross Margin (A-B) } & $10,789.66$ & 899.14 \\
\hline
\end{tabular}

Source: Authors' calculations

In the structure of production value, the most important elements were: annual milk production per dairy cow (4.211 liters), as well as the total amount of milk produced during the lactation period (for 12 cows 50,536 liters delivered to dairies). The following elements were the value of calves, heifers, weaned cows and manure. 
The prices shown in the calculation of the gross margin calculation were the current prices on the market, at the time of the survey. Thus, the average price of male calves was $€ 593.37$ per piece, female calves $€ 461.51$, heifers $€ 1$ 1,500, culled cows $€ 803.53$, manure $€ 82.41$ per 10 tons. In total value of production, incomes realized on the basis of subsidies, that belong to the milk production line were also calculated. The structure of these subsidies consisted of incentives for quality breeding dairy cows of $€ 206.03$ per cow and a premium for delivered milk of $€ 0.06$ per liter.

The structure of the value of production was as follows: income from milk sold about $43 \%$, livestock sale $33.51 \%$, subsidies $19.86 \%$ and manure $3.64 \%$.

The structure of variable costs consisted of the costs of animal feed, hired labor, energy and fuel, costs of services (costs of veterinary services, insemination costs and selection costs), as well as other costs (costs of straw for bedding, medicines used, issuing milk tickets, selling tickets, costs of consumables - detergents, disinfectants, towels, small tools).

The costs of animal represent the largest percentage of the variable production costs in the calculation of the gross margin with about $73 \%$, or in absolute sum $€ 11,940.85$. This costs consist of three items: feed for dairy cows, feed for heifers and concentrated feed for calves. Hired labor is the next item that burdens the gross margin calculation the most - with $17 \%$.

Table 3. Critical values in milk production

\begin{tabular}{|l|r|}
\hline \multicolumn{1}{|c|}{ Description } & $\boldsymbol{\epsilon}($ lit $) /$ head \\
\hline Expected yield/average milk production $(\mathrm{EY})$ & lit 4,211 \\
\hline Expected price $(\mathrm{EP})$ & $€ 0.23$ \\
\hline Subsidies (s) & $€ 448.98$ \\
\hline Variable costs $(\mathrm{VC})$ & $€ 1,362$ \\
\hline Critical price: $\mathrm{CP}=(\mathrm{VC}-\mathrm{s}) / \mathrm{EY}$ & $€ 0.22$ \\
\hline Critical yield: $\mathrm{CY}=(\mathrm{VC}-\mathrm{s}) / \mathrm{EP}$ & lit 3,968 \\
\hline Critical variable costs: $\mathrm{CVC}=(\mathrm{EY} \times \mathrm{EP})+\mathrm{s}$ & $€ 1,418$ \\
\hline
\end{tabular}

Source: Authors' calculations

The calculation of critical values provides insight into how profitable milk production can be, and at what point it becomes unprofitable. From this research it is clear that the level of workload is extremely low, i.e. $0.01 €$. Critical values are calculated only for milk production, without taking calculating income from the sale of livestock, which makes $33 \%$ of the total income. Sensitive analysis performed in order to determine critical values confirmed the results obtained by the calculations shown in Table 3 .

Table 4 shows the structure of production values and variable costs in milk processing into traditional milk products - cream and white cheese. 
Table 4. Gross margin of the variable costs in milk processing into traditional milk products cream and white cheese

\begin{tabular}{|c|c|c|c|c|c|c|}
\hline Description & Quantity & Unit & $\begin{array}{c}\text { Unit price } \\
(€)\end{array}$ & Total $(€)$ & \multicolumn{2}{|c|}{ Per head (€) } \\
\hline \multicolumn{7}{|l|}{ A. Production value } \\
\hline White cheese & 11,623 & $\mathrm{~kg}$ & 2.47 & $28,736.61$ & & $2,394.72$ \\
\hline Skimmed cream & 3,790 & $\mathrm{~kg}$ & 6.18 & $23,425.91$ & & $1,952.16$ \\
\hline Curd & 35,123 & lit & 0.01 & 347.35 & & 28.95 \\
\hline Male calves sold & 6 & head & 593.37 & $3,560.24$ & & 296.69 \\
\hline Female calves sold & 2 & head & 461.51 & 923.03 & & 76.92 \\
\hline Heifers sold & 2 & head & $1,500.00$ & $3,000.00$ & & 250.00 \\
\hline Culled cows & 2 & head & 803.53 & $1,607.05$ & & 133.92 \\
\hline $\begin{array}{l}\text { Subsidy for milking } \\
\text { cows }\end{array}$ & 12 & head & 206.03 & $2,472.39$ & & 206.03 \\
\hline \multicolumn{4}{|l|}{ Manure } & \multicolumn{2}{|r|}{988.96} & 82.41 \\
\hline \multicolumn{4}{|c|}{ Production value (Total A) } & \multicolumn{2}{|r|}{$65,061.54$} & $5,421.80$ \\
\hline \multicolumn{7}{|l|}{ B. Variable costs } \\
\hline \multicolumn{4}{|l|}{ Feed } & \multicolumn{2}{|r|}{$11,940.85$} & 995.07 \\
\hline \multicolumn{4}{|l|}{ Labour } & \multicolumn{2}{|r|}{$4,512.12$} & 376.01 \\
\hline \multicolumn{4}{|l|}{ Energy and fuel } & \multicolumn{2}{|r|}{$1,337.36$} & 111.45 \\
\hline \multicolumn{4}{|l|}{ Contract work } & \multicolumn{2}{|r|}{765.00} & 63.75 \\
\hline \multicolumn{4}{|l|}{ Other } & \multicolumn{2}{|r|}{385.76} & 32.15 \\
\hline \multicolumn{4}{|l|}{ Costs of transport } & \multicolumn{2}{|r|}{741.04} & 61.75 \\
\hline \multicolumn{4}{|c|}{ Rental costs at market stalls } & \multicolumn{2}{|r|}{$1,279.05$} & 106.59 \\
\hline \multicolumn{4}{|c|}{ Packing for cheese products } & \multicolumn{2}{|r|}{$1,778.32$} & 148.19 \\
\hline \multicolumn{4}{|l|}{ Rennet } & \multicolumn{2}{|r|}{191.58} & 15.97 \\
\hline \multicolumn{4}{|l|}{ Salt } & \multicolumn{2}{|r|}{114.32} & 9.53 \\
\hline \multicolumn{4}{|c|}{ Variable costs (Total B) } & \multicolumn{2}{|r|}{$23,045.40$} & $1,920.45$ \\
\hline \multicolumn{4}{|c|}{ C. Gross Margin (A-B) } & \multicolumn{2}{|r|}{$42,016.14$} & $3,501.34$ \\
\hline
\end{tabular}

Source: Authors' calculations

The value of production in Table 4 consists, among others, of the value of skimmed cream and white cheese, as well as whey. The average market price of white cheese is $€ 2.47$, multiplied by $11,623 \mathrm{~kg}$ of cheese produced thus the value of $€ 28,736.61$ is obtained. The average market price for skimmed cream is $€ 6.18$ which is multiplied by $3,790 \mathrm{~kg}$ of produced cream and makes $€ 23,425.91$. Annual production of whey is 35,123 liters, which is multiplied by the market price of $€ 0.01$ which gives a value of $€ 347.35$.

The processing costs shown in the gross margin calculation are: rennet, salt, market packaging, electricity, water, labor involved in milk processing, transportation to the market and stand rental.

The costs of rennet, salt and packaging amount to $€ 2,084.22$. Costs of milk processing, and the costs of water used in processing are added to the amount of fuel and energy (Table 2.). These costs are defined farms in the sample, engaged in processing. Concerning transportation, it was calculated that the producer takes the products to the green market twice a week, so that annually he/she travels about 600 kilometers from 
the farm to the nearby green market, which multiplied by the price of diesel of $€ 1.29$ per liter amounts $€ 741.04$. The cost of renting a stand varied depending on the place surveyed. The figure of $329.65 €$ was taken for the annual stand renting. Daily cost of stand renting, which is paid extra, averaged around $10 €$, so it was taken that the total cost of stand renting was $€ 1,279.05$.

The costs of the labor engaged in milk processing are calculated as given in Table 2, with additionally engaged labor that is temporarily hired for work in processing, as well as in product placement. The survey of farms engaged in processing, have shown that, on average, 6 hours of work per day were spent for milk processing and marketing of dairy products, which amounts to $€ 1,804.85$ annually.

Tables 5 and 6 show the calculations of critical values in the production of white cheese and skimmed cream.

Table 5. Critical values in the production of white cheese

\begin{tabular}{|l|r|}
\hline \multicolumn{1}{|c|}{ Description } & $\boldsymbol{\epsilon}(\mathbf{k g}) / \mathbf{h e a d}$ \\
\hline Expected yield/average milk procession $(\mathrm{EY})$ & $\mathrm{kg} 969$ \\
\hline Expected price $(\mathrm{OP})$ & $€ 2.47$ \\
\hline Subsidies (s) & $€ 188.86$ \\
\hline Variable costs $(\mathrm{VC})$ & $€ 1.920$ \\
\hline Critical price: $\mathrm{CP}=(\mathrm{VC}-\mathrm{s}) / \mathrm{EY}$ & $\mathrm{kg} 701$ \\
\hline Critical yield: $\mathrm{CY}=(\mathrm{VC}-\mathrm{s}) / \mathrm{OP}$ & $€ 2,581$ \\
\hline Critical variable costs: $\mathrm{CVC}=(\mathrm{EY} \times \mathrm{OP})+\mathrm{s}$ & \\
\hline
\end{tabular}

Source: Authors' calculations

Table 6. Critical values in the production of skimmed cream

\begin{tabular}{|c|c|}
\hline Description & $€(\mathrm{~kg}) / \mathrm{head}$ \\
\hline Expected yield/average milk procession (EY) & $\mathrm{kg} 316$ \\
\hline Expected price (OP) & $€ 6.18$ \\
\hline Subsidies (s) & $€ 188.86$ \\
\hline Variable costs (VC) & $€ 1,920$ \\
\hline Critical price: $\mathrm{CP}=(\mathrm{VC}-\mathrm{s}) / \mathrm{EY}$ & $€ 5.48$ \\
\hline Critical yield: $\mathrm{CY}=(\mathrm{VC}-\mathrm{s}) / \mathrm{OP}$ & $\operatorname{kg} 280$ \\
\hline Critical variable costs: $C V C=(E Y \times O P)+s$ & $€ 2,141$ \\
\hline
\end{tabular}

Source: Authors' calculations

Production of traditional dairy products, in this case skimmed cream and white cheese, can withstand market turbulence. The price of cream can be reduced by $0.7 €$, while keeping the positive value of the margin. The situation with white cheese is similar - the load or price drop can go up to $0.68 €$. Sensitive analysis, which was also conducted in order to confirm the calculation of the critical values, gave similar results. 
Table 7. Comparative analysis of milk production and processing

\begin{tabular}{|l|l|c|}
\hline Row. no. & \multicolumn{1}{|c|}{ Comparative analisys of milk production and procession } & Amount (€/lit) \\
\hline $\mathbf{1 .}$ & Parameters of milk production and procession & 0.21 \\
\hline $\mathbf{1 . 1 .}$ & Production price per litter of milk & 0.29 \\
\hline $\mathbf{1 . 2 .}$ & Production price with premium & 0.08 \\
\hline $\mathbf{1 . 3 .}$ & Financial result per litter of milk sold & 0.46 \\
\hline $\mathbf{2 .}$ & Parameters of production and sales of processed milk & 1.29 \\
\hline $\mathbf{2 . 1 .}$ & Production price of processed milk & 0.83 \\
\hline $\mathbf{2 . 2 .}$ & Prices of the sold processed milk & 0.24 \\
\hline $\mathbf{2 . 3 .}$ & Financial result per litter of processed milk & 1.00 \\
\hline $\mathbf{3 .}$ & Difference & 0.75 \\
\hline $\mathbf{3 . 1 .}$ & Difference in the price of produced and processed milk \\
\hline $\mathbf{3 . 2 .}$ & Difference in price of raw and processed milk & \multicolumn{2}{|l}{} \\
\hline $\mathbf{3 . 3 .}$ & Difference in financial result &
\end{tabular}

Source: Authors' calculations

A comparative analysis of milk production and processing with the given parameters, shows the financial result per liter of sold/processed milk. In milk production, the average production price per liter of milk from the surveyed sample was $€ 0.21$, while the selling price per liter of milk, including premium, was $€ 0.29$, which gives the financial result per liter of milk sold of $€ 0.08$. In milk processing, i.e. production of skimmed cream and white cheese, the average production price per liter of processed milk is $€ 0.46$, and the average selling price per liter of processed milk for these two products is $€ 1.29$. The financial result per liter of processed milk in this model is $0.83 €$.

The difference between the production price of raw and processed milk per liter is $€$ 0.24 , the difference between the selling price of raw and processed milk per liter is $€$ 1 , and the difference in the final financial result per liter of processed milk is $€ 0.75$.

\section{Conclusions}

The main actors of milk production in Serbia are small family farms with a maximum of 9 dairy cows. One of the main limiting factors for increasing the number of cows on family farms in the Republic of Serbia is the fragmentation of households, i.e. limited resources for animal feed production.

By introducing adequate technology, a significant amount of milk can be processed into traditional milk products within family farms, such as various types of cheese and other dairy products that can be successfully valorized on the market. This can significantly increase the value of milk and thus the profitability of milk production.

Traditional dairy products are characterized by original technology and specific properties, determined by the areas where milk is produced. They are recognizable on the market, which provides the opportunity to create significant added value. 
Achieved production results of raw milk production on a small farm, obtained in this research (Table 2.), lead to the following conclusions:

- $\quad$ positive gross margin was achieved ( $€ 10,789.66$ / basic herd, i.e. $€ 899.14$ / milking cow, i.e. $€ 0.21$ / liter of raw milk);

- achieved value of production after selling milk, cattle and manure is 1.66 times higher than variable production costs;

- the feed costs comprise the largest share in variable costs $(73 \%)$.

Achieved production results of skimmed cream and white cheese production on a small farm (Table 4.), lead to the following conclusions:

- $\quad$ positive gross margin was achieved $(€ 42,016.14$ / basic herd, i.e. $€ 3,501.34$ / milking cow, i.e. $€ 0.83$ / liter of milk);

- achieved value of production after selling milk, cattle and manure is 2.82 times higher than variable production costs;

- the feed costs comprise the largest share in variable costs $(52 \%)$, followed by the processing costs $(28 \%)$.

By comparing two productions - raw milk production and production of traditional dairy products, on anual level and by observing the results shown in Table 7, it can be concluded that the sales prices of dairy products are significantly higher than raw milk prices, as well as that a better financial result is achieved in the production dairy products. Particularly, when comparing the production price of raw milk of $€ 0.21$ and the selling price of $€$ 0.29 , it is questionable whether the difference in the financial result of $€ 0.08$ can cover fixed costs in milk production. On the other hand, it is clear that the difference in the financial result per liter of processed milk of $€ 0.83$ can certainly cover fixed costs. The total difference in the financial result is $0.75 €$ per liter of processed milk, i.e. $75 €$ cents per liter of milk remains a positive financial difference in the case when the agricultural producer processes own milk into traditional dairy products, in this case skimmed cream and white cheese. When the obtained result is multiplied by the total amount of milk produced, an income of $€ 37,902$ ( $0.75 € * 50,536$ lit) is obtained.

The results of the research clearly show that the economic efficiency of milk processing into traditional dairy products is on a very high level.

The achieved economic results in milk processing cover the fixed costs of production and that there is also a surplus that can be used for new investments on the farm. It should be noted that this type of production of traditional dairy products is ideal for farms that have a basic herd of about 12 milking cows.

\section{Acknowledgements}

This paper is result of the research within the contract on the implementation and financing of scientific in 2020 between the Institute for Science Application in 
Agriculture, Belgrade and the Ministry of Education, Science and Technological Development of the Republic of Serbia, contract number: 451-03-68/2020-14/200045, as well as the contract between the Ministry of Education, Science and Technological Development of the Republic of Serbia and the Faculty of Agriculture University of Novi Sad, contract number: 451-03-68/2020-14/200117.

\section{Conflict of interests}

The authors declare no conflict of interest.

\section{References}

1. Andrić, J. (1998). Costs and calculations in agricultural production, Faculty of Agriculture Belgrade, Belgrade.

2. Census of Agriculture 2012. (2013). Agriculture in the Republic of Serbia, The Statistical Office of the Republic of Serbia, Belgrade.

3. European statistics (EUROSTAT), Retrieved from https:/ec.europa.eu/eurostat/ (January 21, 2020).

4. Gogić, P. (2014). Theory of costs with calculations in production and processing of agricultural products, Poljoprivredni fakultet, Beograd.

5. Janković, D., Miladinov, J., Rodić, V., \& Bošnjak, D. (2014). Farm diversification: a case study in the municipality of Novi Kneževac. Agroekonomika, 43(63-64), 50-62.

6. Janković, D. (2012). Territorial approach to regional rural development. Economics of Agriculture, 59(4), 675-686.

7. Janković, D., \& Novakov, M. (2019). Serbia and rural development - rural sociological reviews, Faculty of Agriculture, Novi Sad.

8. Joksimović, M., Ivanović, S., \& Janković Šoja, S. (2020). Production and tendency in milk processing in Montenegro. Economics of Agriculture, 67(2), 391-404. doi: http://doi.org/10.5937/ekoPolj2002391J

9. Jović, L., Kosanović, N., \& Vukadinović, P. (2015). Analysis of subventions for agriculture in Republic of Serbia and Republic of Srpska. Economics of Agriculture, 62(4), 963-974. doi: http://doi.org/10.5937/ekoPolj1504963J

10. Kosanović, N., Jović, Lj., \& Tomić, V. (2016). Model of reintegration of returnees after readmission into agribusiness sector, Institute for science application in agriculture, Belgrade.

11. Milić, D., Tica, N., Zekić, V., Popov, M., Mihajlov, Z., \& Šepa, A. (2020). Methods for assessing the economic viability of biogas plant investments. Journal on Processing and Energy in Agriculture, 24, 13-17.

12. Milić, D., Glavaš-Trbić, D., Tomaš Simin, M., Zekić, V., Novaković, T., \& Popov, M. (2019). Economic characteristics of sour cream production in small-scale dairy processors in Serbia. Economic of Agriculture, 66(3), 787-798. doi: http://doi. org/10.5937/ekoPolj1903787M 
13. Milić, D., Glavaš-Trbić, D., Tomaš Simin, M., Zekić, V., \& Novaković, T. (2019). Economic charachteristics of yogurt production in a small capacity dairies in Serbia. Agroeconomics, 48(84), 65-75.

14. Milić, D., Glavaš-Trbić, D., Tomaš-Simin, M., Janković, D., \& Zekić, V. (2016). Economic characteristics of grape production in south Banat. Economics of Agriculture, 63(4), 1187-1203. doi: http://doi.org/10.5937/ekoPolj1604187M

15. Ministry of Agriculture, Forestry and Water Management, Veterinary Directorate Republic of Serbia, Electronic database, Retrieved from www.vet.minpolj.gov.rs, (December 20, 2019).

16. Mitrović, M. (2015). Villages in Serbia - Changes in the structure and sustainable development issues, The Statistical Office of the Republic of Serbia, Retrieved from http://publikacije.stat.gov.rs/G2015/Pdf/G20154009.pdf (February 05, 2020).

17. Munćan, P., \& Božić, D. (2017). Farm size as a factor of emloyment and income of members of family farms. Economics of Agriculture, 64(4), 1483-1498. doi: http:// doi.org/10.5937/ekoPolj1704483M

18. Nielsen, L., Mitchell, F., \& Norreklit, H. (2015). Management accounting and decision making: Two case studies of outsourcing. Acounting Forum, 39, 64-82.

19. Novakov, M., Janković, D., \& Petrović, M. (2018). Family and sociocultural characteristics of the owners of selected farms in Vojvodina. Economics of Agriculture, 65(3), 1015-1030. doi: http://doi.org/10.5937/ekoPolj1803015N

20. Popescu, G., \& Andrei, J. (2011). From industrial holdings to subsistence farms in Romanian agriculture. Analyzing the subsistence components of CAP. Agricultural Economics, 57(11), 555-564. doi: http://doi.org/10.17221/72/2010-AGRICECON

21. Popović Vranješ, A. (2015). Special cheese-making, Faculty of Agriculture, Novi Sad.

22. Popović Vranješ, A., Krstović, S., Jurakić, Ž., Popović, M., Šaran, M., \& Vlahović, B. (2017). Models of small cheese producing plants. Agroeconomics, 46(76), $67-$ 78.

23. Serbian Agricultural Market Information System, Electronic database, Retrieved from www.stips.minpolj.gov.rs, (February 04, 2020).

24. Subić J., \& Tomić, V. (2019). Programs for investing in safe food processing (milk, meat, fruits and vegetables) on small households. Improving knowledge transfer in order to ensure safe and competitive agricultural products, obtained by processing agriculture products in sectors of dairy, meat, fruits and vegetables, 93-157.

25. Subić, J., Jeločnik, M., \& Zubović, J. (2015). Application of irrigation as an agrotechnical measure - analysis of cover margin in maize production. Ecologica, 22(78), 245-251.

26. Subić, J., Ivanović, L., \& Jeločnik, M. (2010). Sensitive analysis of livestock breeding production on family farms. Economics of Agriculture, 57(2), 312-320. 
27. Survey on the structure of agricultural holdings 2018. (2019). What it confirms, what it denies and what it points to, The Statistical Office of the Republic of Serbia, Belgrade.

28. The Statistical Office of the Republic of Serbia, Electronic database, Retrieved from www.stat.gov.rs, (January 24, 2020).

29. Tomić, V., Janković, S., Kuzevski, J., Ljiljanić, N., \& Radišić, R. (2013). Maize gross margins in different environmental conditions in 2011 and 2012. 50th Anniversary Department of Agricultural Economics/The Seminar Agriculture and Rural Development - Challenges of Transition and Integration Processes, Faculty of Agriculture, Belgrade, 1(1), 226-234.

30. Vasiljević, Z., \& Tomić, V. (2016). Business risk management on an agricultural households and insurance system in the field agriculture in Serbia, Improvement of financial knowledge and record keeping on agricultural households in the Republic of Serbia, 71-94.

31. Zekić, S., Mijić, K., Jakšić, D., \& Milenković, I. (2016). Profitability gap in the milk production chain: evidence from Serbia. Economics of Agriculture, 63(2), 485-499. doi: http://doi.org/10.5937/ekoPolj1602485Z 